\title{
PENGARUH KUALITAS PELAYANANTERHADAP KEPUASAN KONSUMEN INDOMARET KOTA BUKIT PURWAKARTA
}

\author{
${ }^{1)}$ Muliawan, ${ }^{2)}$ Muhlis \\ ${ }^{1)}$ Alumni Program Studi Manajemen, STIE Dewantara \\ J1. Raya Pemda Bojong Depok Baru III, Karadenan, Cibinong, Bogor, Jawa Barat 16913, Indonesia \\ Email: mulyawanjkusuma@gmail.com \\ ${ }^{2)}$ Dosen Program Studi Manajemen, STIE Dewantara \\ J1. Raya Pemda Bojong Depok Baru III, Karadenan, Cibinong, Bogor, Jawa Barat 16913,Indonesia \\ Email: muhlis@dewantara.ac.id
}

\begin{abstract}
The presence of Alfamart near Indomaret which has been standing, it will cause a scramble for customers between Indomart and Alfamart. This is happen at Indomaret of Kota Bukit Purwakarta that caused a decline in the average number of customers per day which shopping. On 2006 Indomaret at Kota Bukit has decreased that significantly by 22.22\% compared to the average number of daily customers of 2005. The condition of latest, the average number of daily customers on 2007 (Januari-April) is decreasing as much as 1.20\% compared to the average daily benefit of 2006. The research aims to understand the influence of the quality of service for customer satisfaction at Indomaret of Kota Bukit Purwakarta with full and simultaneous. The population that used is the customers Indomaret of Kota Bukit Purwakarta and sample is taken using Slovin formulas with the levels of trust $90 \%$. The data analyze is used Multiple Linier Regression. The result of the research is to inform the quality of service which includes the tangible, realibility, responsive, assurance and empathy to depend on the particular satisfaction simultaneously. Responsive variable is variable which influence with full and has the biggest impact on customers satisfaction Indomaret of Kota Bukit Purwakarta.
\end{abstract}

Keywords: Indomaret, Service and Satisfaction.

\begin{abstract}
ABSTRAK
Kehadiran Alfamart dilokasi gerai Indomaret yang telah berdiri, akan menyebabkan perebutan konsumen antara Indomaret dan Alfamart. Kondisi ini terjadi di Indomaret Kota Bukit Purwakarta menyebabkan penurunan jumlah rata-rata konsumen perhari yang berbelanja. Indomaret Kota Bukit tahun 2016, mengalami penurunan yang sangat signifikan sebesar 22,22\% dibandingkan dengan rata-rata jumlah konsumen harian tahun 2015. Kondisi terbaru, rata-rata jumlah konsumen harian tahun 2017 (Jan-Apr) juga mengalami penurunan sebesar $1,20 \%$ dibandingkan dengan rata-rata omzet harian tahun 2016. Penelitian ini bertujuan untuk mengetahui pengaruh kualitas pelayanan terhadap kepuasan konsumen Indomaret Kota Bukit Purwakarta secara parsial dan simultan. Populasi yang digunakan adalah konsumen Indomaret Kota Bukit Purwakarta dan sampel diambil menggunakan rumus Slovin dengan tingkat kepercayaan 90\%. Analisis data menggunakan Regresi Linier Berganda. Hasil penelitian menginformasikan kualitas pelayanan yang meliputi tangible, realibility, responsive, assurance dan empathy berpengaruh terhadap kepuasan secara simultan. Variabel responsive merupakan variabel yang berpengaruh secara parsial dan memiliki pengaruh terbesar terhadap kepuasan konsumen Indomaret Kota Bukit Purwakarta.
\end{abstract}

Kata kunci: Indomaret, Pelayanan dan Kepuasan.

\section{PENDAHULUAN}

Perkembangan dan persaingan bisnis ritel saat ini sangat cepat dan ketat besaing terutama pada segmen minimarket. Dua minimarket yang selalu bersaing adalah Indomaret dan Alfamart. Kedua minimarket terkadang hadir bersamaan dalam satu lokasi, saling memperebutkan konsumen yang sama.

Kondisi ini mengharuskan kedua minimarket saling bersaing dalam berbagai aspek, baik aspek marketing mix ataupun 
pelayanan. Aspek pelayanan merupakan salah satu cara meraih hati konsumen dan mempertahankan hati kosumen biar tidak berpindah ke pesaing.

Kehadiran Alfamart dilokasi gerai Indomaret yang telah berdiri terlebih dahulu, akan menyebabkan perebutan konsumen antara Indomaret dan Alfamart. Kondisi ini terjadi di Indomaret Kota Bukit Purwakarta menyebabkan penurunan jumlah rata-rata konsumen perhari yang berbelanja.

Kondisi Indomaret Kota Bukit Purwakarta setelah pembukaan Alfamart bulan Desember 2015 dengan jarak dua ruko di peroleh data, rata-rata jumlah konsumen harian yang berbelanja di toko Indomaret Kota Bukit tahun 2016, mengalami penurunan yang sangat signifikan sebesar $22,22 \%$ dibandingkan dengan rata-rata jumlah konsumen harian tahun 2015.

Kondisi terbaru, rata-rata jumlah konsumen harian tahun 2017 (Jan - Apr) juga mengalami penurunan sebesar $1,20 \%$ dibandingkan dengan rata-rata omzet harian tahun 2016.

Berdasarkan latar belakang tersebuk maka dilakukan kajian "pengaruh kualitas pelayanan terhadap kepuasan konsumen Indomaret Kota Bukit Purwakarta" dengan tujuan untuk:

1. Mengetahui pengaruh kualitas pelayanan terhadap kepuasan konsumen Indomaret Kota Bukit Purwakarta secara parsial.

2. Mengetahui pengaruh kualitas pelayanan terhadap kepuasan konsumen Indomaret Kota Bukit Purwakarta secara simultan.

3. Mengetahui Variabel yang paling berpengaruh dan dominan terhadap kepuasan konsumen Indomaret Kota Bukit Purwakarta.

\section{TINJAUAN PUSTAKA}

Dalam mengukur kualitas jasa pelayanan digunakan dimensi kualitas jasa yang dikemukakan oleh Parasuraman, Zeithaml dan Berry (2003). Kelima karakteristik kualitas pelayanan tersebut adalah :

1. Tangible (bukti langsung) meliputi fasilitas fisik, perlengkapan, pegawai dan sarana komunikasi

2. Reability (keandalan) yaitu kemampuan memberikan pelayanan yang dijanjikan dengan segera, akurat dan memuaskan.

3. Responsive (daya tanggap) yaitu keinginan para staf untuk membentuk para pelanggan dan memberikan pelayanan dengan tanggap

4. Assurance (jaminan) yang mencakup pengetahuan, kemampuan, kesopanan dansifat dapat dipercaya yang dimiliki para staf bebas dari bahaya, resiko atau keragu- raguan.

5. Empathy (empati) meliputi kemudahan dalam melakukan hubungan, komunikasi yang baik, perhatian pribadi dan memahami kebutuhan pelanggan

Menurut Evans (1990), konsumen (kadang-kadang disebut dengan pengguna atau pengguna akhir), adalah individu, organisasi, atau bagian dari organisasi yang menggunakan, menghabiskan, atau mengkonsumsi produk dan jasa.

Sementara menurut Gaspersz (2002), mendefinisikan konsumen sebagai orang yang menuntut kita (atau perusahaan kita) untuk memenuhi standar kualitas tertentu dan karena itu akan memberikan pengaruh pada kinerja kita.

Tjiptono at all (2001), Menguraikan definisi konsumen menurut pandangan modern mencakup konsumen eksternal yakni setiap orang yang membeli produk 
dari perusahaan, sedangkan konsumen internal adalah semua pihak dalam organisasi yang sama yang menggunakan jasa suatu bagian tertentu. Menurut definisi ini, konsumen adalah orang atau pihak yang dilayani kebutuhannya

Menurut Kotler (2003), kepuasan merupakan perasaan seseorang menyenangkan atau kecewa setelah membandingkan kinerja produk (atau hasil) dalam hubungannya dengan harapan konsumen.

Sedangkan kepuasan konsumen, menurut Kuswandi (2004) adalah perbedaaan antara harapan dan persepsi konsumen terhadap apa yang diberikan perusahaan kepada mereka. Jika harapan konsumen terhadap apa yang akan diberikan perusahaan rendah dan ternyata persepsinya terhadap apa yang telah diberikan perusahaan kepada mereka tinggi, konsumen akan merasakan kepuasan.

\subsection{Kerangka Pemikiran}

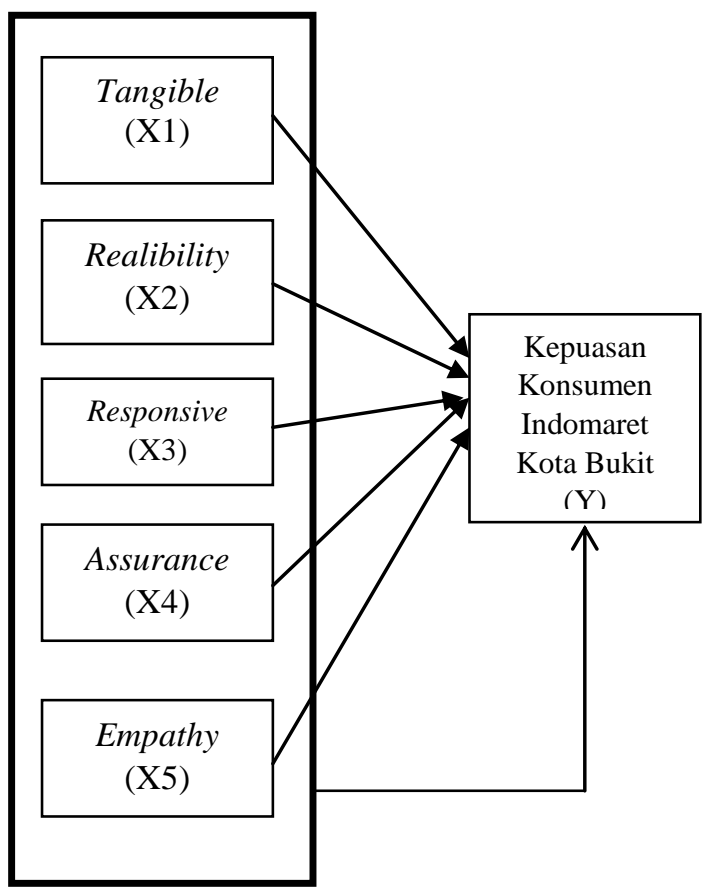

Gambar 1. Kerangka Pemikiran PenelitianHipotesa
H0: Tidak terdapat pengaruh kualitas pelayanan terhadap kepuasan konsumen Indomaret Kota Bukit Purwakarta.

H1: Terdapat pengaruh tangible pelayanan terhadap kepuasan kosumen Indomaret Kota Bukit Purwakarta.

$\mathrm{H} 2$ : Terdapat pengaruh realibilty pelayanan terhadap kepuasan kosumen Indomaret Kota Bukit Purwakarta.

H3: Terdapat pengaruh responsive pelayanan terhadap kepuasan kosumen Indomaret Kota Bukit Purwakarta.

H4: Terdapat pengaruh assurance pelayanan terhadap kepuasan kosumen Indomaret Kota Bukit Purwakarta.

H5: Terdapat pengaruh empathy pelayanan terhadap kepuasan kosumen Indomaret Kota Bukit Purwakarta.

H6: Terdapat pengaruh pelayanan secara simultan terhadap kepuasan kosumen Indomaret Kota Bukit Purwakarta.

\section{METODE PENELITIAN}

Dalam penelitian ini populasi yang digunakan adalah konsumen yang berbelanja di Indomaret Kota Bukit Purwakarta. Responden dalam penelitianini adalah konsumen yang melakukan pembelian minimal dua kali di Indomaret Kota Bukit Purwakarta.

Jumlah sampel yang diambil menggunakan rumus slovin (Umar, 2007) sebagai berikut:

$$
\begin{aligned}
\mathrm{n} & =\mathrm{N} /\left(1+\mathrm{Ne}^{2}\right) \\
& =13980 /\left(1+13980(0,01)^{2}\right) \\
& =99,29 \text { dibulatkan } 100
\end{aligned}
$$

Dimana:

$$
\begin{aligned}
\mathrm{N}= & \text { populasi (jumlah konsumen bulan } \\
& \text { Januari-Maret } 2017=13.980) \\
\mathrm{e}= & \text { Margin of error }(10 \%)
\end{aligned}
$$


Teknik pengambilan sampel di lakukan dengan accidental sampling yaitu pengambilan sampel berdasarkan pada saat tersebut, siapa saja yang kebetulan bertemu dengan peneliti dapat digunakan sebagai sampel jika responden dipandang cocok sebagai sumber data (Ferdinand, 2006).

Data dianalisis menggunakan:

1. Uji validitas, gunakan untuk mengukur sah atau valid tidaknya suatu kuesioner. Suatu kuesioner dikatakan valid jika pertanyaan pada kuesioner mampu untuk mengungkap sesuatu yang akan diukur oleh kuesioner tersebut (Ghozali, 2001). Pertanyaan dikatakan valid bila $r-$ hitung > r-tabel.

2. Uji realibilitas, uji ini untuk mengukur kehandalan suatu kuesioner yang merupakan indikator dari variabel. Suatu kuesioner dikatakan reliabel atau handal jika jawaban seseorang terhadap pertanyaan adalah konsisten atau stabil dari waktu ke waktu (Ghozali, 2001). kuisioner dikatakan handal bila nilai cronbah's alpa > 0,60 .

3. Uji normalitas, uji ini untuk menguji apakah dalam model regresi, variabel dependen dan variabel independen mempunyai distribusi data normal atau mendekati normal. Data berdistribusi normal bila nilai sig > 0,10 .

4. Uji heteroskedastisitas, uji ini dilakukan untuk menganalisis apakah dalam model regresi terdapat ketidaksamaan variance dari residual satu pengamatan ke pengamatan lain. Hasil dapat dilihat dari grafik Scatterplot antara nilai prediksi variabel dependen dengan residualnya. Apabila membentuk pola tertentu atau teratur maka mengidentifikasikan telah terjadi heterokedastisitas. sebaliknya apabila titik-titik yang ada menyebar di atas dan di bawah angka 0 sumbu Y, maka tidak terjadi heterokedastisitas (Ghozali, 2001).

5. Uji multikolineritas, untuk menguji apakah model regresi ditemukan adanya korelasi antarvariabel bebas. Model yang baik seharusnya tidak terjadi korelasi diantara variabel independen dan tidak orthogonal atau nilai korelasi antarsesama variabel independen sama dengan nol. Dapat juga dilihat dari nilai Tolerance dan Variance Inflation Factor (VIF), nilai Tolerance yang besarnya di atas 0,1 dan nilai VIF di bawah 10 menunjukkan bahwa tidak ada multikolinearitas pada variabel independennya (Ghozali, 2001).

6. Regresi linier berganda digunakan untuk mengetahui pengaruh dari variabel bebas terhadap variabel terikat.

7. Uji t untuk mengetahui apakah vaiabel independen (Tangible, Reliability, Responsive, Assurance, Empathy) secara parsial berpengaruh signifikan terhadap variabel dependen (Kepuasan Konsumen).

Berdasarkan nilai $\mathrm{t}$ hitung dan $\mathrm{t}$ tabel dinyatakan:

- Jika nilai t hitung > t tabel maka variable independen berpengaruh terhadap variable dependen.

- Jika nilai $\mathrm{t}$ hitung $\leq \mathrm{t}$ tabel maka variable independen tidak berpengaruh terhadap variable dependen

8. Uji f untuk mengetahui secara bersama-sama pengaruh variabel independen (Tangible, Reliability, Responsive, Assurance, Empathy) terhadap variabel dependen (Kepuasan Konsumen).

Berdasarkan nilai $f$ hitung dan $\mathrm{f}$ tabel dinyatakan:

- Jika nilai f hitung > f tabel maka variable independen berpengaruh 
secara bersama-sama terhadap variable dependen.

- Jika nilai $\mathrm{t}$ hitung $\leq \mathrm{t}$ tabel maka variable independen tidak berpengaruh secara bersama-sama terhadap variable dependen

9. Uji determinasi, uji in digunakan untuk mengetahui tingkat yang paling baik antara dua variabel atau digunakan untuk mengukur besarnya kontribusi (share) dari variabel $\mathrm{X}$ terhadap variasi naik turunnya variabel Y yang biasanya dinyatakan dalam presentase, (Ghozali, 2011).

\section{HASIL DAN PEMBAHASAN}

\subsection{Uji Validitas}

Tabel 1. menunjukkan bahwa semua indikator yang digunakan untuk mengukur variabel-variabel yang digunakan dalam penelitian ini mempunyai koefisien korelasi yang lebih besar dari r-tabel,untuk sampel sebanyak 100 orang nilai r-tabel yaitu 0.165. Nilai $r$ hitung yang disajikan pada tabel di atas menunjukkan bahwa semua indikator tersebut adalah valid.

Tabel 1. Hasil Uji Validitas

\begin{tabular}{|c|c|c|c|}
\hline $\begin{array}{c}\text { No } \\
\text { Soal }\end{array}$ & r hitung & $r$ tabel & Ket \\
\hline 1 & $.452^{* *}$ & 0.165 & Valid \\
\hline 2 & $.628^{* *}$ & 0.165 & Valid \\
\hline 3 & $.664^{* *}$ & 0.165 & Valid \\
\hline 4 & $.598^{* * *}$ & 0.165 & Valid \\
\hline 5 & $.653^{* *}$ & 0.165 & Valid \\
\hline 6 & $.688^{* * *}$ & 0.165 & Valid \\
\hline 7 & $.769^{* *}$ & 0.165 & Valid \\
\hline 8 & $.662^{* *}$ & 0.165 & Valid \\
\hline 9 & $.766^{* *}$ & 0.165 & Valid \\
\hline 10 & $.756^{* *}$ & 0.165 & Valid \\
\hline 11 & $.684^{* *}$ & 0.165 & Valid \\
\hline 12 & $.738^{* * *}$ & 0.165 & Valid \\
\hline 13 & $.799^{* *}$ & 0.165 & Valid \\
\hline 14 & $.752^{* *}$ & 0.165 & Valid \\
\hline 15 & $.668^{* *}$ & 0.165 & Valid \\
\hline 16 & $.582^{* *}$ & 0.165 & Valid \\
\hline 17 & $.700^{* *}$ & 0.165 & Valid \\
\hline 18 & $.723^{* *}$ & 0.165 & Valid \\
\hline 19 & $.741^{* *}$ & 0.165 & Valid \\
\hline 20 & $.750^{* *}$ & 0.165 & Valid \\
\hline 21 & $.773^{* *}$ & 0.165 & Valid \\
\hline 22 & $.765^{* *}$ & 0.165 & Valid \\
\hline 23 & $.777^{* *}$ & 0.165 & Valid \\
\hline 24 & $.730^{* *}$ & 0.165 & Valid \\
\hline 25 & $.737^{* *}$ & 0.165 & Valid \\
\hline 26 & $.413^{* *}$ & 0.165 & Valid \\
\hline 27 & $.640^{* *}$ & 0.165 & Valid \\
\hline 28 & $.698^{* *}$ & 0.165 & Valid \\
\hline 29 & $.669^{* *}$ & 0.165 & Valid \\
\hline 30 & $.553^{* *}$ & 0.165 & Valid \\
\hline
\end{tabular}

Sumber: data diolah, tahun 2017

\subsection{Realibilitas}

Tabel 2. Hasil Uji Realibilitas

\begin{tabular}{|c|c|}
\hline Cronbach's Alpha & N of Items \\
\hline .958 & 30 \\
\hline
\end{tabular}

Sumber: data diolah, tahun 2017

Hasil uji reliabilitas tersebut menunjukkan bahwa semua variabel mempunyai koefisien Alpha yang cukup besar yaitu diatas 0.60 , Nilai Cronbach Alpha yang ternyata lebih besar dari 0.60 , artinya reliable, sehingga dapat dikatakan semua konsep pengukur variabel kualitas pelayanan dari kuesioner adalah reliabel 
yang berarti bahwa kuesioner yang digunakan dalam penelitian ini merupakan kuesioner yang handal.

\subsection{Uji Normalitas}

\section{Tabel 3. Hasil Uji Normalitas}

\begin{tabular}{|ll|r|}
\hline & & \multicolumn{2}{|c|}{$\begin{array}{c}\text { Unstandardized } \\
\text { Residual }\end{array}$} \\
\hline $\mathrm{N}$ & Mean & 100 \\
Normal & Std. & 0 \\
Parameters & Deviation & 2.0427682 \\
& Absolute & 0.076 \\
Most Extreme & Positive & 0.076 \\
Differences & Negative & -0.063 \\
Test Statistic & & 0.076 \\
Asymp. Sig. (2-tailed) & $.161^{\mathrm{c}}$ \\
\hline
\end{tabular}

Sumber: data diolah, tahun 2017

Tabel 3. Menunjukan nilai signifikasi sebesar 0,161 lebih besar dari 0,10 sehingga data berdistribusi normal.

\subsection{Uji Heteroskedastisitas}

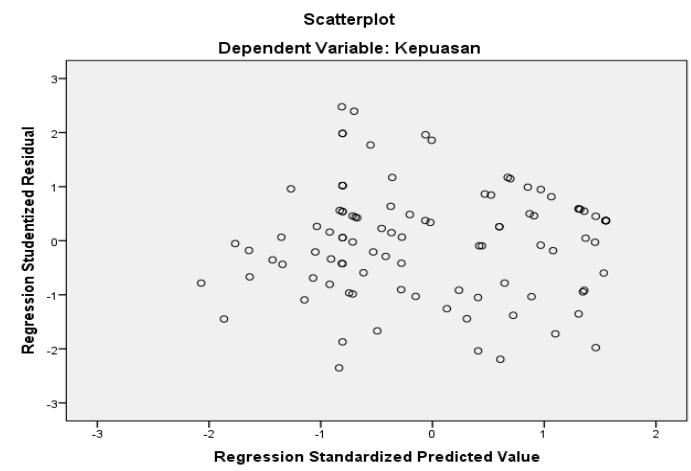

Gambar 2. Hasil Uji Heteroskedstisitas

Pengujian heteroskedastisitas dilakukan dengan menggunakan Scatter Plot. Hasil menunjukan titik-titik yang ada pada Gambar 1. menyebar di atas dan di bawah angka 0 sumbu $\mathrm{Y}$, maka tidak terjadi heteroskedastisitas. $\mathrm{Hal}$ ini menunjukan model regresi tidak memiliki gejala heteroskedastisitas, artinya tidak ada gangguan yang berarti dalam model regresi ini.

\subsection{Uji Multikolineritas}

Tabel 4. Hasil Uji Multikolineritas

\begin{tabular}{|l|c|c|c|}
\hline Variable & Tolerance & VIF & Keterangan \\
\hline Tangible & .527 & 1.897 & tidak terjadi \\
Reliability & .283 & 3.527 & tidak terjadi \\
Responsive & .353 & 2.832 & tidak terjadi \\
Assurance & .290 & 3.450 & tidak terjadi \\
Empathy & .340 & 2.944 & tidak terjadi \\
\hline
\end{tabular}

Sumber: data diolah, tahun 2017

Hasil pengujian dapat dilihat pada Tabel 4. menunjukkan bahwa semua variabel yang di gunakan sebagai prediktor model regresi menunjukkan nilai VIF di bawah nilai 10 dan nilai tollerance diatas 0,1 .

Hal ini berarti bahwa variabel-variabel bebas yang di gunakan dalam penelitian ini tidak menunjukkan adanya gejala mulitikoliniearitas.

\subsection{Regresi Linier Berganda}

Tabel 5. Hasil Uji Regresi Linier Berganda

\begin{tabular}{|l|c|c|c|c|}
\hline \multirow{2}{*}{ Model } & \multicolumn{2}{|c|}{$\begin{array}{c}\text { Unstandardized } \\
\text { Coefficients }\end{array}$} & \multirow{2}{*}{$\mathrm{T}$} & \multirow{2}{*}{ Sig. } \\
\cline { 2 - 3 } & $\mathrm{B}$ & Std. Error & & \\
\hline (Constant) & 2.458 & 2.299 & 1.069 & 0.288 \\
Tangible & 0.167 & 0.130 & 1.284 & 0.202 \\
Reliability & 0.213 & 0.161 & 1.317 & 0.191 \\
Responsive & 0.451 & 0.147 & 3.061 & 0.003 \\
Assurance & 0.012 & 0.164 & 0.072 & 0.943 \\
Empathy & 0.029 & 0.140 & 0.204 & 0.839 \\
\hline
\end{tabular}

Sumber: data diolah, tahun 2017

Berdasarkan hasil uji regresi linear berganda seperti tampak pada Tabel 5 . diperoleh persamaan regresi yaitu:

$\mathrm{Y}=\mathbf{2 . 4 5 8}+0.167 \mathrm{X} 1+0.213 \mathrm{X} 2+0.451$ X3 + 0.012X4+ 0.029 X5.

Nilai koefisien regresi dari variabel di atas menunjukkan besarnya pengaruh variabel bebas terhadap variabel terikat. emakin besar nilai pada koefisien variabel 
bebas (X), maka semakin besar pula pengaruhnya terhadap variabel terikat $(\mathrm{Y})$.

Dari hasil uji diketahui bahwa variabel yang paling besar mempengaruhi kepuasan konsumen Indomaret Kota Bukit adalah variabel responsive dengan nilai koefisien regresi sebesar 0.451, dimana setiap variable responsive ditingkatkan satu satuan maka kepuasan konsumen Indomaret Kota Bukit Purwakarta akan naik satu 0.451 satuan.

\subsection{Uji T}

Hasil uji t pada Tabel 5 diatas, dapat dijelaskan sebagai berikut:

1. Variabel tangible dengan t-hit $1.284<$ t-tabel 1.661, maka H0 diterima dan H1 ditolak.

2. Variabel reability dengan t-hit $1.317<$ t-tabel 1.661, maka H0 diterima dan $\mathrm{H} 2$ ditolak.

3. Variabel responsive dengan t-hit 3.061 $>$ t-tabel 1.661, maka H0 ditolak dan H3 diterima.

4. Variabel assurance dengan t-hit 0.072 $<$ t-tabel 1.661, maka H0 diterima dan H4 ditolak.

5. Variabel empathy dengan t-hit $0.204<$ t-tabel 1.661, maka H0 diterima dan H5 ditolak.

Hasil uji $\mathrm{t}$ menunjukan bahwa variabel responsive secara parsial berpengaruh terhadap kepuasan konsumen Indomaret Kota Bukit.

\subsection{Uji F}

Tabel 6. Hasil Uji F

\begin{tabular}{|l|c|r|r|c|c|}
\hline Model & $\begin{array}{l}\text { Sum of } \\
\text { Squares }\end{array}$ & Df & $\begin{array}{c}\text { Mean } \\
\text { Square }\end{array}$ & F & Sig. \\
\hline Reg & 338.193 & 5 & 67.639 & 15.39 & $.000^{\mathrm{b}}$ \\
Res & 413.117 & 94 & 4.395 & & \\
\hline Total & 751.31 & 99 & & & \\
\hline
\end{tabular}

Sumber: data diolah tahun 2017
Hasil uji f dimana nilai f-hit 15,39> dari f-tabel 1.91, maka H0 ditolak dan H6 diterima. Hasil uji menunjukan bahwa secara bersama-sama variabel tangible, realibility, responsive, assurance dan empathy berpengaruh terhadap kepuasan konsumen Indomaret Kota Bukit.

\subsection{Uji Determinasi}

Tabel 7. Hasil Uji Determinasi

\begin{tabular}{|c|c|r|c|c|}
\hline Model & $\mathrm{R}$ & $\begin{array}{c}\mathrm{R} \\
\text { Square }\end{array}$ & $\begin{array}{c}\text { Adjusted } \\
\text { R Square }\end{array}$ & $\begin{array}{c}\text { Std. Error } \\
\text { of the } \\
\text { Estimate }\end{array}$ \\
\hline 1 & $.671^{\mathrm{a}}$ & .450 & .421 & 2.096 \\
\hline
\end{tabular}

Sumber: data diolah, tahun 2017

Tabel 7. diatas menunjukan nilai koefisien determinasi $\mathrm{R}$ yang menunjukan tingkat hubungan antara variabel bebas terhadap variabel terikat yaitu 0,671 atau mendekati 1 artinya terdapat hubungan yang moderat. Dan adjusted $R$ square menunjukan besarnya kontribusi 0,421 atau $42,1 \%$ dari kualitas pelayanan terhadap kepuasan konsumen Indomaret Kota Bukit sementara sisanya 0,579 atau $57,9 \%$ berupa kontribusi dari faktor-faktor lain yang tidak termasuk dalam penelitian ini.

\section{KESIMPULAN DAN SARAN}

\subsection{KESIMPULAN}

Hasil penelitian analisis kualitas pelayanan terhadap kepuasan konsumen Indomaret Kota Bukit dapat disimpulkan sebagai berikut:

1. Persamaan regresi berganda menunjukan hasil sebagai berikut: $\mathrm{Y}=2,458+0,167 \mathrm{X} 1+0,213 \mathrm{X} 2+$ $0,451 \mathrm{X} 3+0,012 \mathrm{X} 4+0,029 \mathrm{X} 5$

2. Berdasarkan analisis secara parsial melalui uji t, bahwa variable responsive merupakan variable yang berpengaruh terhadap kepuasan konsumen dan merupakan variabel yang berpengaruh paling besar terhadap kepuasan konsumen. 
3. Berdasarkan analisis secara bersamasama melalui uji f, bahwa variabel tangible, reliability, responsive, assurance dan empathy berpengaruh secara bersama-sama terhadap kepuasan konsumen.

4. Hasil uji determinasi menunjukan bahwa $42.1 \%$ kepuasan konsuen Indomaret Kota Bukit dipengaruhi oleh varibel pelayanan.

\subsection{SARAN}

1. Variable responsive dapat lebih diperkuat dan ditingkatkan dalam meningkatkan pelayanan ke konsumen Indomaret Kota Bukit.

2. Hasil penelitian menunjukkan masih ada 57,9\% dipengaruhi oleh aspek lain yang tidak diteliti, oleh karena itu perlunya dilakukan penelitian lebih lanjut untuk aspek lainya dalam penelitian mengenai kepuasan konsumen Indomaret Kota Bukit.

\section{DAFTAR PUSTAKA}

Evans, David. Marketing, Oxford: Oxford University Press, 1990.

Ferdinand, Augusty. 2006, "Metode Penelitian Manajemen", Pedoman Penelitian Untuk Penulisan Skripsi, Tesis dan Disertasi Ilmu Manajemen, Badan Penerbit Universitas Diponegoro.

Gaspersz. 2002. Vincent. Total Quality Management, Jakarta: PT.Gramedia Pustaka Utama,

Ghozali, Imam. 2011. Aplikasi Analisis Multivariate Dengan Program SPSS. Semarang: Badan Penerbit Universitas Diponegoro.

Kotler, Philip. 2003. Marketing Management, Internatioanl Edition. New Jersey: Prentiee Hall.

Kuswandi, Cara Mengukur Kepuasan Karyawan (Jakarta: PT. Elex Media Komputindo Kelompok Gramedia,
2004).

Parasuraman A, Valarie A Zeithaml and Leonard L Berry, 2003, Reassessment of Implication For Further Research. Journal Marketing

Tjiptono, Fandy dan Anastasia Diana. 2001. TQM: Total Quality Management. Yogyakarta: Andi.

Umar, Husein. 2007. Metode Penelitian Untuk Skripsi dan Tesis Bisnis. Jakarta : PT. Raja Grafindo Persada. 